\title{
Improve Ramp-Up Performance on the Sewing Process in a Sports Shoe Factory Using 8-Disciplines and Lean Manufacturing
}

\author{
DOI: 10.12776/QIP.V25I2.1516
}

Lucky Setiawan, Sawarni Hasibuan

Received: 2020-10-29 Accepted: 2021-03-14 Published: 2021-07-31

\begin{abstract}
Purpose: The research aims to design a performance improvement framework for a new model of sports shoes to increase the ramp-up process time.

Methodology/Approach: The approach used the problem-solving system of 8 disciplines, Single Minute Exchange Dies, Visual Management, and the Just In Time principle.

Findings: By using the methods described above, the research findings will have a positive impact on the company. Model changeover time was reduced from 600 minutes to 102 minutes, and ramp-up time was reduced from 20 days to 2 days.

Research Limitation/Implication: The limitation of this study was that only the CK2946 model was still done as a case study. The cost and other inhibiting factors were also not included in the discussion of this rump-up process.

Originality/Value of paper: By integrating SMED, Just In Time, visual management, and using 8-Dicipline, the researcher developed a framework for improved performance for ramping up a new model of sports shoes.
\end{abstract}

Category: Case study

Keywords: ramp-up; changeover; SMED; just in time; visual management 


\section{INTRODUCTION}

The global development trend of the footwear industry showed an increase with average production growth of $3.05 \%$ in the period from 2015 to 2019 , but the global consumption rate was downward in 2019 (Black and Létis, 2018; APICCAPS, 2020b; APICCAPS, 2020a). Indonesia ranks fourth in the world as a footwear manufacturer after China, India, and Vietnam (Kemenperin, 2019), where Indonesia produced 1.2 billion pairs of shoes in 2018, contributing about $6.4 \%$ to the global total production of shoes. However, there had been a decrease in national consumption in 2019 due to the impact of the pandemic outbreak of Covid19 (APRISINDO, 2018; Kemenperin, 2019; Huda, 2020; Krishna, 2020). If the average growth in shoe consumption worldwide for the period 2015 to 2018 was only $2.6 \%$, then the average consumption growth in the same period will reach $6 \%$ at the national level. During the last five years, the average growth in Indonesia's shoe production was $5.7 \%$, higher than the $3.05 \%$ global average growth. In addition to being promoted to the local market, Indonesian shoe products were also exported to the global market, which accounts for $46 \%$ of the shoes produced.

The footwear industry is a group of the fashion industry that is required to develop innovative products to boost market competitiveness. In Indonesia, the footwear industry is classified as a labour-intensive industry, relying on its production processes on the use of large-scale human labour (Pujiastuti, 2015; APRISINDO, 2018). In addition to expanding to different regions to improve efficiency and decrease labour costs (International Labour Organization, 2016), this industry is also constantly increasing the range of its products.

The increasing variety of new models, particularly in sewing process lines, can have an impact on machine setup time and operator skills in production lines. The ability of the operator to perform the process can decrease as the model changes from one model to another, which has a different process that can result in decreased production process efficiency (Kentli, Dal and Alkaya, 2013) and also increase the sewing process ramp-up time is a long time. Ramp-up time is the time it takes until the line reaches its daily production target for the first material to enter the line. Ramp-up is a phase in mass production from the development of product samples, processes, and production systems until the first product output that suits the customer is achieved. The production quantity increases with the instability of machines, processes, and people are working until the conditions are stable and the production quantity desired is reached during the ramp-up stage (Dombrowski, Wullbrandt and Krenkel, 2018).

As one of the multi-national companies producing sports shoes in Indonesia, with an average of 18 new shoe models each year, PT PAI always produces new shoe models. This causes the ramp-up time performance to be longer in the sewing process, resulting in decreased sewing line productivity. Based on the last 6 models, the average ramp-up time in the sewing process at PT PAI was around 20 days, with the best time was 13 days, while competitor benchmarks can reach 
10 days (interviewed result on March 23, 2020). PT PAI needs to make improvements to compete in national and global markets, because the main processes in a shoe company are basically the same, namely cutting, sewing, and assembly (Briciu and Ofileanu, 2015).

\section{LITERATURE REVIEW}

Researchers have widely adopted the concept of lean manufacturing to increase productivity and minimize costs in the manufacturing process (Uzun Kocamiş, 2015; Karam et al., 2018). The concept used in time-related lean production is just in time and SMED (Single Minute Exchange Dies) is associated with model change. In various industries, such as the iron industry, the apparel industry, and the telecommunications panel industry (Gavali, Chavan and Dongre, 2016; Mulyana and Hasibuan, 2017; Singla and Pal, 2017; Zerin, Hossain and Zannat, 2019), SMED is widely used to solve rapid transition problems in the production process(Esa, Rahman and Jamaludin, 2015; Jagtap et al., 2015; Filla, 2016; Gavali, Chavan and Dongre, 2016; Arief and Ikatrinasari, 2018; Syafei and Lokadipati, 2018; Agung and Hasbullah, 2019; Talekar et al., 2019). The application of SMED in the clothing industry had been a success in reducing the replacement time of the model between 0.45-12.6 hours (Singla and Pal, 2017), while the replacement time in the apparel industry had reduced by 283.81 minutes (Zerin, Hossain and Zannat, 2019), It can reduce the retooling time by up to 6 minutes in the food industry (Maalouf and Zaduminska, 2019), it can saved setup time by up to 12 minutes in the pharmaceutical industry (Arief and Ikatrinasari, 2018), it can reduce setup time by up to 9 minutes in the copper cable industry (Setyawan, 2019).

Several problem-solving tools, such as PDCA (Plan, Do, Check, Action) and DMAIC (Define-Measure-Analyze-Improve-Control), are widely used today. PDCA is a traditional approach used to solve medium-scale problems and implies that the PDCA cycle must be restarted in the Act phase to ensure continuous improvement, as in (Sunadi, Purba and Hasibuan, 2020) which uses the PDCA method to increase the process capability. In concept, however, the PDCA can still be enhanced again, so that the process's ability can even be better. In conjunction with the six sigma methods, the DMAIC method is generally used. The DMAIC approach is essentially similar to the PDCA approach, which is carried out in 5 stages and is often associated with statistical tools that address product quality in the control of the process of product defects (Trimarjoko et al., 2019). Compared to the PDCA and DMAIC methods, the 8-Discipline method has a more detailed phase: D0 (planning), D1 (team building), D2 (defining and explaining the problem), D3 (implementing temporary corrective actions), D4 (root cause analysis), D5 (permanent fix action), D6 (implementing permanent corrective action), D7 (preventing the same problem) and D8 (Tim recognition) follow the following steps in the 8-Discipline method (Zarghami and Benbow, 2017). In phases D0 to D4, 
the phase plan in 8-Disciplines is discussed in more detail to make it easier to plan improvements. Phases D0, D1, and D8 have complete methods that do not have the two previous methods for starting and ending a project.

The SMED concept was applied by several previous studies with a focus on improving the fast changeover time on the internal setup of the process and the machine itself. Meanwhile, in preparing to replace the new model at this time, the performance of the sewing process for the new model of sports shoes cannot be separated from communication with other departments. To support problem-solving related to delays from other departments, the concept of just in time and visual management is required. As a reference for a framework for the development of new shoes, particularly sports shoes, the results of the integration of the SMED, just in time, and visual management methods with the 8-Discipline method can be used.

\section{METHODOLOGY}

This study is a case study carried out by a multinational sports shoe company in Indonesia and was conducted from November 2019 to February 2020. The steps taken to solve the problem in this case are:

- Steps 1: Problem Identification

- Ramp-up data achievement

- Interviewed (Production leader, production manager, etc.)

○ Determine research objectives

- Determine research framework (Figure 1)

- Steps 2: Literature study

○ Eight Disciplines theory, Lean Concept, Pull system, SIPOC, SMED

○ Literature review

- Steps 3: Data collection

○ Collect ramp-up time

- Breakdown setup activities

- New model schedule plan

- Steps 4: Data Analysis

- Internal Factors (calculate sewing process setup and Compared cycle time in each process with line balancing (Takt time)

- External Factors (list Item are used to the framework of the sewing process) 
- Steps 5: Improvement

○ Improvement is made by the 8-Discipline steps (Table 1)

- Steps 6: Evaluation

○ Tracking project result based on the next new model

- Evaluate the achievement of the framework timeline

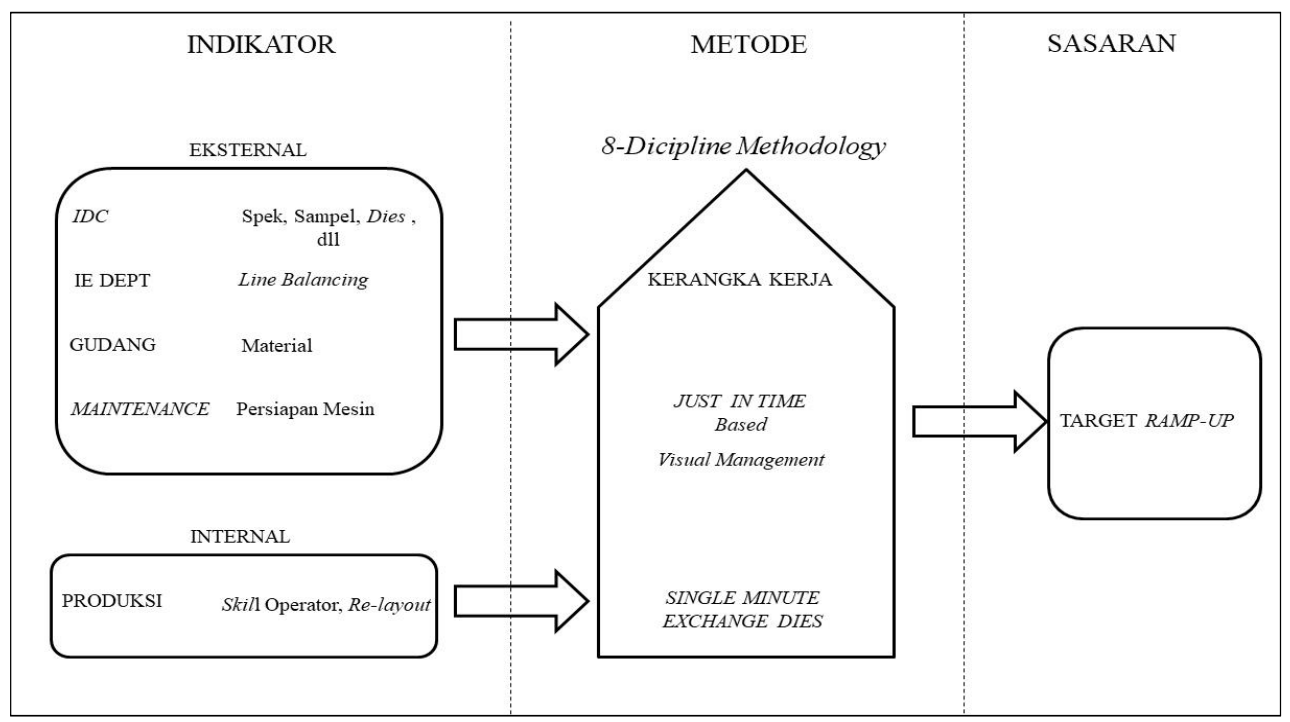

Figure 1 - Research Framework

Figure 1 depicts a system for explaining the issues caused by external and internal causes that are the target of problem indicators. The 8-Discipline approach is supposed to be able to identify and solve problems as a result of improvement measures. The SMED, JIT, and Visual Management approach offers tools for making changes such that issues can be solved and not recur. These three approaches would result in the development of a framework operation as a means of achieving management's planned ramp-up goals, as well as joint-supervision.

In this study, the data used consisted of primary and secondary data. The primary data was collected through direct observation, interviews, and brainstorming. The 8-Disciplines process was the step used in this case study. The initial stage was presented in Table 1. Through the planning of the project schedule (D0). The next step was to create a project team to enhance the success of the new model ramp-up process involving the Department of Production, the Department of Innovation Development Center, the Department of Industrial Engineering, the Lean Department, the Department of Warehouse, the Department of Engineering, and the Sister Company (D1). The industrial engineering department collected secondary data at the ramp-up performance of each new model. 
Table 1 - 8-Discipline Corrective Steps for Improved Performance of the Sewing Process (Gemba Academy, 1998)

\begin{tabular}{|c|c|c|c|c|c|c|c|c|c|c|c|}
\hline \multirow{2}{*}{$\begin{array}{l}\text { Kaizen Event Description } \\
\text { Preparation / Kaizen / Follow Up }\end{array}$} & \multicolumn{11}{|c|}{ Kaizen Timeline } \\
\hline & 15 & 22 & 29 & 05 & 12 & 19 & 26 & 02 & 09 & 16 & \multirow[t]{2}{*}{ Ramp-up } \\
\hline & \multicolumn{3}{|c|}{$\begin{array}{l}\text { December } \\
2019\end{array}$} & \multicolumn{4}{|c|}{$\begin{array}{c}\text { January } \\
2020\end{array}$} & \multicolumn{3}{|c|}{$\begin{array}{l}\text { February } \\
2020\end{array}$} & \\
\hline D0: Project planning & $\mathrm{X}$ & & & & & & & & & & \\
\hline D1: Forming a Team & $\mathrm{X}$ & & & & & & & & & & \\
\hline D2: Define the problem & $\mathrm{X}$ & $\mathrm{X}$ & & & & & & & & & \\
\hline D3: Temporary prevention & \multicolumn{11}{|c|}{ Previous model } \\
\hline D4: Root caused analysis & & & $\mathrm{X}$ & $\mathrm{X}$ & $\mathrm{X}$ & $\mathrm{X}$ & & & & & \\
\hline D5: Plan for Improvements & & & $\mathrm{X}$ & $\mathrm{X}$ & $\mathrm{X}$ & $\mathrm{X}$ & & & & & \\
\hline D6: Corrective action & & & & & & & & $\mathrm{X}$ & $\mathrm{X}$ & $\mathrm{X}$ & \\
\hline D7: Prevent the problem & & & & & & & & $\mathrm{X}$ & $\mathrm{X}$ & $\mathrm{X}$ & $\mathrm{X}$ \\
\hline D8: Recognition Team & \multicolumn{11}{|c|}{ When monthly Meeting } \\
\hline
\end{tabular}

\section{RESULT AND DISCUSSION}

The main problem defined (D2) was the unachievable ramp-up time in the sewing process which causes low productivity and late delivery of the six new models. With the coordination of the Project Team, each department made temporary improvements (D3) including The IDC Department compared the specs and the job of production operators to ensure quality, the Industrial Engineering Department and the Trial Team helped to improved operator skills so that the process cycle time was achieved according to the line balancing sheets, and the Maintenance Department and production leaders speed up the completion of the layout process.

Using the brainstorming method, analysis of the root cause of the problem (D4) was carried out and the results were presented in a fishbone diagram. 4 variables, namely humans, materials, techniques, and machines, were the problem of delays in the ramp-up time. Bottleneck issues were identified from the human factor in critical processes (internal sewing). The causes were not only due to internal activities (the layout process and machine settings were carried out on the D-day) but also due to external factors from the machine, material, and method factors, as could be seen in Figure 2.

Problems could be classified into two groups, namely the internal sewing process and the external sewing process (including the cutting process). The internal sewing process was improved by the use of the SMED method due to the long changeover time activity. Meanwhile, for external factors due to delays in the 
equipment preparation activities that preceded the sewing process, but the team did not identify which department the team was repairing by creating a new model performance improvement framework to anticipate delays with a just-intime approach and visual management.

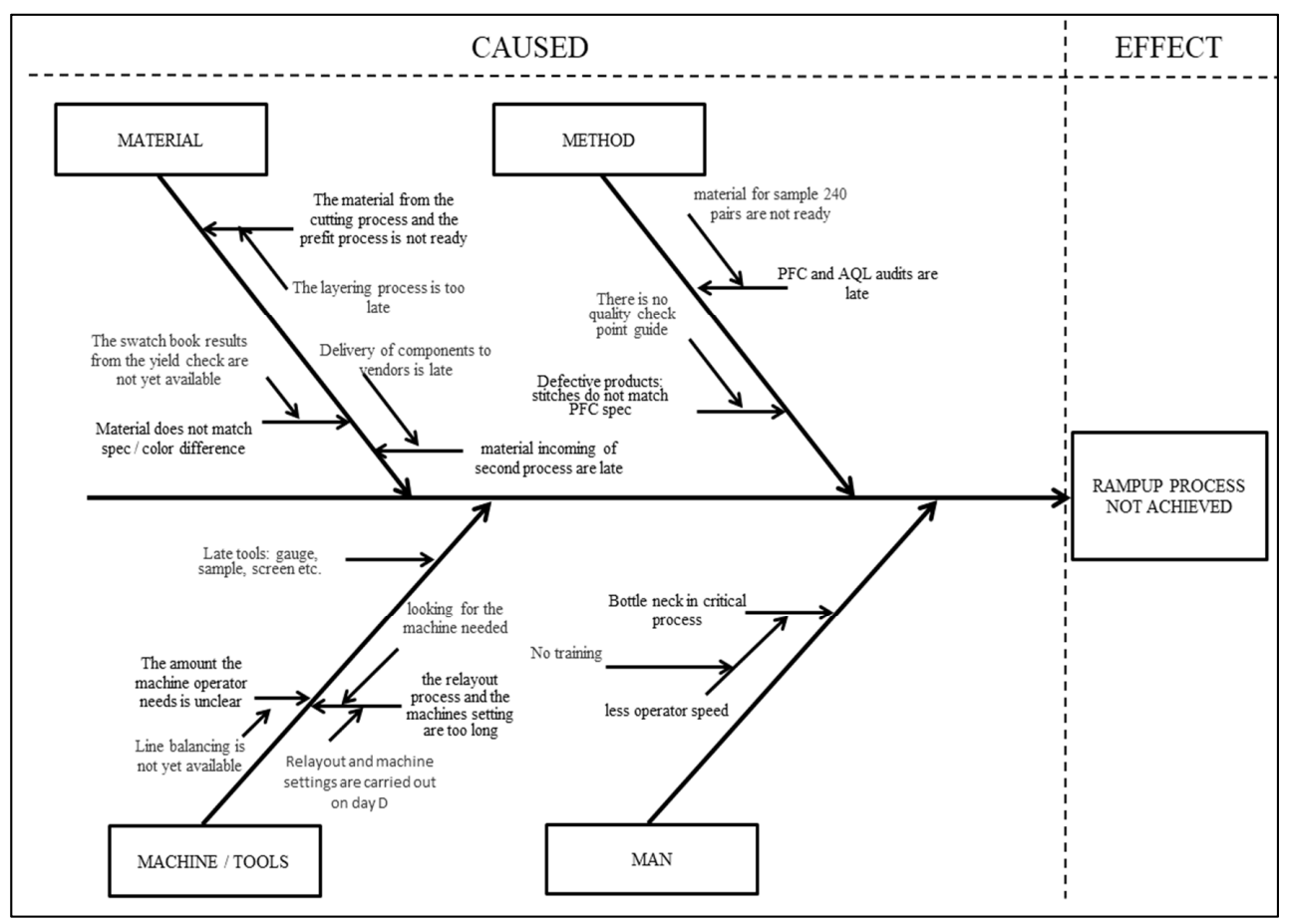

Figure 2 - Fishbone Diagram of Ramp-up Process Is Not Achieve

(Cotton, 2016)

Due to the change over time, which was too long, the improvement carried out (D5) on the internal sewing process reach 10 hours (600 minutes), as described in Table 2.

Table 2 - Current Situation Changeover Activity

\begin{tabular}{|c|c|c|c|c|}
\hline Task & Activities & $\begin{array}{l}\text { Internal/ } \\
\text { External }\end{array}$ & $\begin{array}{c}\text { Code } \\
\text { Activity }\end{array}$ & $\begin{array}{c}\text { Time } \\
\text { (minute) }\end{array}$ \\
\hline \multirow[t]{2}{*}{$\begin{array}{l}\text { Sewing Team } \\
\text { Leader (assisted } \\
\text { by operator) }\end{array}$} & $\begin{array}{l}\text { 1. Prepare the machine needed, tooling and } \\
\text { compile the layout of the machine } \\
\text { 2. Allocation the operator's task } \\
\text { 3. Attached quality check point }\end{array}$ & $\begin{array}{l}\text { Internal } \\
\text { Internal } \\
\text { Internal }\end{array}$ & A & 300 \\
\hline & 4. Training of critical processes & Internal & B & 600 \\
\hline Maintenance & $\begin{array}{l}\text { 1. Change needle type and stitch step setting } \\
\text { (stitch per inch) } \\
\text { 2. Computer sewing machine program settings }\end{array}$ & $\begin{array}{l}\text { Internal } \\
\text { Internal }\end{array}$ & $\mathrm{C}$ & 450 \\
\hline
\end{tabular}


Following the brainstorming of the team between the production and maintenance teams, an improvement plan was proposed by changing some of the internal activities to the external ones presented in Table 3. The results of this brainstorming have been used as targets for the activities of the proposed new model framework.

Table 3 - Plan to Change Activities from Internal to External

\begin{tabular}{|l|l|l|l|}
\hline \multicolumn{1}{|c|}{ Task } & \multicolumn{1}{|c|}{ Activities } & \multicolumn{1}{|c|}{$\begin{array}{l}\text { Internal/ } \\
\text { external }\end{array}$} & Note \\
\hline $\begin{array}{l}\text { Team Leader } \\
\text { sewing \& } \\
\text { Auditor }\end{array}$ & $\begin{array}{l}\text { 1. Prepare the } \\
\text { machine and } \\
\text { tooling }\end{array}$ & External & $\begin{array}{l}\text { Machine preparation with H-10 dead line and } \\
\text { numbering to be affixed to the sewing machine. }\end{array}$ \\
\hline Maintenance & $\begin{array}{l}\text { 2. Change the } \\
\text { needle type }\end{array}$ & External & $\begin{array}{l}\text { The needle change is done after the machine has } \\
\text { been numbered by the Team Leader. }\end{array}$ \\
\hline Maintenance & $\begin{array}{l}\text { 3. Computer } \\
\text { sewing machine } \\
\text { program settings }\end{array}$ & External & $\begin{array}{l}\text { Computer sewing machine settings can be done } \\
\text { on H-10. }\end{array}$ \\
\hline $\begin{array}{l}\text { Team Leader } \\
\text { sewing }\end{array}$ & $\begin{array}{l}\text { 4. Allocation the } \\
\text { operator's task }\end{array}$ & External & The allocation of tasks can be done on the D-10. \\
\hline $\begin{array}{l}\text { Team Leader } \\
\text { sewing \& Team } \\
\text { Trial }\end{array}$ & $\begin{array}{l}\text { 5. Training critical } \\
\text { Process }\end{array}$ & External & $\begin{array}{l}\text { Training for critical process operators will be } \\
\text { on D-7 and regular processes on D-6. }\end{array}$ \\
\hline $\begin{array}{l}\text { Team Leader } \\
\text { sewing, } \\
\text { operator sewing } \\
\text { \& Maintenance }\end{array}$ & $\begin{array}{l}\text { 6. Compiling } \\
\text { Machine Layout }\end{array}$ & Internal & $\begin{array}{l}\text { The process of compiling the layout is set to a } \\
\text { target of 90 minutes and will be carried out } \\
\text { on D-6. }\end{array}$ \\
\hline $\begin{array}{l}\text { Team Leader } \\
\text { sewing }\end{array}$ & $\begin{array}{l}\text { 7. Attached quality } \\
\text { check point }\end{array}$ & Internal \\
\hline $\begin{array}{l}\text { Maintenance } \\
\text { steps (stitch per }\end{array}$ & $\begin{array}{l}\text { The quality check point can be attached together } \\
\text { with the process number on the table. }\end{array}$ \\
\hline
\end{tabular}

Apart from internal problems, delays in the ramp-up process were also often caused by the late receipt by the production department of support items from other departments by the sequence of activities. For example, the Industrial Engineering Department was often late in delivering line balancing sheets, as a result of which the production department was late in determining the number and type of sewing machines to be assigned to operators. Delays in the sewing process resulted in the sequential activity being disrupted in such a way that the management ramp-up target was not achieved. Delays in the sewing process may also cause the assembly process to be delayed, resulting in late delivery to customers. It is on this basis that the team proposes a framework for a new shoe model to improve ramp times. Table 4 illustrates the framework of the sewing process. This framework sets a timeline for each activity so that the target rampup time can be reached. It is clear from Table 4 that there are 4 preparations 
tooling activities on D-15. Green Visual is given if the target is reached, otherwise, Red Visual is given when it is too late.

Table 4 - Proposed Activity Framework for New Model Shoes Sewing Section

\begin{tabular}{|c|c|c|c|c|c|c|}
\hline Area & & & WING & & & \\
\hline Part & & Activity & Deadline & Target & Status/ & Note \\
\hline Sewing & 1. Tooling & 1. PFC/SPEC & $\mathrm{H}-15$ & 28-Jan & & \\
\hline & & 2. Component Gauge & $\mathrm{H}-15$ & 28-Jan & & \\
\hline & & 3. Sewing Jig & $\mathrm{H}-15$ & 28-Jan & & \\
\hline & & 4. Original Sample & $\mathrm{H}-15$ & 28-Jan & & \\
\hline & $\begin{array}{l}\text { 2. Line } \\
\text { Balancing }\end{array}$ & $\begin{array}{l}\text { 1. Accept the LB for the } \\
\text { FSR Trial stage }\end{array}$ & H - 15 & 28-Jan & & \\
\hline & & $\begin{array}{l}\text { 2. Line Balancing } \\
\text { Adjustments \& Initial } \\
\text { Production Layout } \\
\text { Arrangements }\end{array}$ & H - 11 & $3-\mathrm{Feb}$ & & \\
\hline & $\begin{array}{l}\text { 3. Transfer The } \\
\text { sewing }\end{array}$ & $\begin{array}{l}\text { 1. Supply of sewing } \\
\text { components }\end{array}$ & $\mathrm{H}-15$ & 28-Jan & & \\
\hline & $\begin{array}{l}\text { TL \& GL } \\
\text { production }\end{array}$ & $\begin{array}{l}\text { 2. Making Job break } \\
\text { down sheets for } \\
\text { critical processes }\end{array}$ & H - 11 & $3-\mathrm{Feb}$ & & \\
\hline & & $\begin{array}{l}\text { 3. Transfer stitching } \\
\text { process }\end{array}$ & $\mathrm{H}-12$ & 31-Jan & & \\
\hline & $\begin{array}{l}\text { 4. Transfer of } \\
\text { stitching }\end{array}$ & $\begin{array}{l}\text { 1. Allocation of } \\
\text { operators task }\end{array}$ & $\mathrm{H}-10$ & 4-Feb & & \\
\hline & $\begin{array}{l}\text { operators } \\
\text { process } \\
\text { critical }\end{array}$ & $\begin{array}{l}\text { 2. Material preparation } \\
\text { for training of } \\
\text { operator process } \\
\text { critical }\end{array}$ & $\mathrm{H}-8$ & 6-Feb & & \\
\hline & & $\begin{array}{l}\text { 3. Teaching operators of } \\
\text { critical processes }\end{array}$ & $\mathrm{H}-7$ & 7-Feb & & \\
\hline
\end{tabular}

The next stage is the corrective action (D6) that had been planned by the production and maintenance team to work together on the improvement plan. The Team Leader prepared line sewing for the new model on the D-10, while the Internal Auditor checked the completeness of the tooling on the temporary sewing machine area. The team leader assigned machine numbers to the line balancing sheet and the quality checkpoints on the table for critical processes. Figure 3 showed the sewing machine for the CK2946 model in the mainline area for process 6 , namely, stitch tongue to tongue lining. Furthermore, Maintenance performs machine settings in a temporary area to reduced workload when relaying was carried out on D-6 days. The Maintenance team changes the needle typesetting for the manual machine or computerized sewing machine which was still being carried out on the same day as the D-10 target and simultaneously the 
team leader had chosen an operator for each process so that on the D day the ramp-up was ready to run the new model process.

The determination of the operator that had already been carried out will determine the critical training phase of the process that would be carried out on D-7 and, in general, the process will be carried out on D-6. The training of critical process was carried out in the line-testing area at the end of the regular working hours (overtime) and will end when the head-line test section decides that the operator has passed with good quality. While there is regular training in the training room to introduce new model products and processes (PFCs) for operators to understand the new model processes, the team leader will also appoint operators to fill the process as well as quality points in each process.

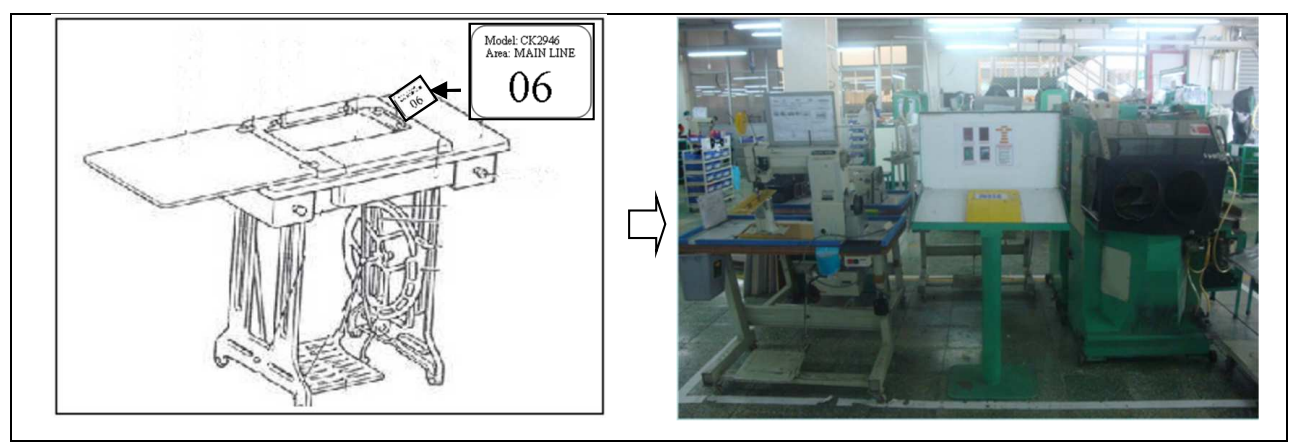

Figure 3 - Numbering on Sewing Machines and Temporary Places for Sewing Machines

The next improvement activity carried out on H-6 is to arrange the layout of the machines according to the line balancing. Machines that had been numbered and set up by the team leader, as well as Maintenance in the temporary area, can be used to compile the layout from the start of process number 1 to process 42 for the mainline area. With the improvements that have already been made, it is hoped that this activity can be completed in no more than 90 minutes. And then Maintenance will set up some of the remaining machines that have not been completed on the D-10, and this activity is expected to take no more than 60 minutes.

The four activities mentioned above are included in the framework activities of the sewing process and are in line with the timeline. The results of the quick changeover with the SMED method provide significant improvements as described in Table 5. 
Table 5 - Process Performance Before and After Changeover Improvements in Sewing Process

\begin{tabular}{|l|c|c|l|l|}
\hline \multicolumn{1}{|c|}{ Activity } & $\begin{array}{c}\text { Before } \\
\text { improvement }\end{array}$ & $\begin{array}{c}\text { After } \\
\text { improvement }\end{array}$ & \multicolumn{1}{|c|}{ Percentage } & Note \\
\hline $\begin{array}{l}\text { Ramp-up } \\
\text { Achievement }\end{array}$ & 20 days & 2 days & $\begin{array}{l}\text { The ramp-up time } \\
\text { would increase by up to } \\
90 \% .\end{array}$ & \\
\hline Re-layout & 300 minute & 68 minute & $\begin{array}{l}\text { The change in sewing } \\
\text { layout increased to } \\
77.33 \%\end{array}$ & $\begin{array}{l}\text { Machine setup time } \\
\text { increased by up to } 90 \% .\end{array}$ \\
\hline Machines setup & 450 minute & 45 minute & $\begin{array}{l}\text { Not all machine setting } \\
\text { activities are done }\end{array}$ \\
\hline Total changeover & 600 minute & 102 minute & $\begin{array}{l}\text { The average turnover } \\
\text { time jumps to } 83 \% .\end{array}$ & $\begin{array}{l}\text { Calculated from the } \\
\text { start of the layout until } \\
\text { the first upper comes } \\
\text { out }\end{array}$ \\
\hline
\end{tabular}

Inline sewing, improvements in internal to external operations resulted in time savings in the re-layout process from 600 minutes to 102 minutes, the set-up time of the engine was also reduced from 450 minutes to 45 minutes, and the layout time was reduced from 300 minutes to 68 minutes. The reduced time setting of the machine helps to develop operator skills across vital processes. Internal changes had made it possible to reduce the ramp-up time from an average of 20 days to just 2 days. Improvement of external factors in the planning of ramp-up products was made possible by monitoring framework activities as summarized in Table 6.

Table 6 - Sewing Areas Framework for the CK2946 Model

\begin{tabular}{|c|c|c|c|c|c|c|}
\hline Style & \multicolumn{6}{|l|}{ CK2946 } \\
\hline Area & \multicolumn{6}{|l|}{ SEWING } \\
\hline Part & \multicolumn{2}{|c|}{ Activity } & Deadline & Target & Status/Date & Note \\
\hline \multirow{6}{*}{$\begin{array}{l}\text { Sewing } \\
\text { Preparation }\end{array}$} & \multirow{4}{*}{$\begin{array}{l}\text { 1. Tooling } \\
\text { preparation }\end{array}$} & 1. PFC/SPEC & $\mathrm{H}-15$ & 28-Jan & 26-Jan & \\
\hline & & $\begin{array}{l}\text { 2. Component } \\
\text { Gauge }\end{array}$ & H-15 & 28-Jan & 26-Jan & \\
\hline & & 3. Sewing Jig & H-15 & 28-Jan & 26-Jan & \\
\hline & & $\begin{array}{l}\text { 4. Original } \\
\text { Sample }\end{array}$ & H-15 & 28-Jan & 26-Jan & \\
\hline & \multirow[t]{2}{*}{$\begin{array}{l}\text { 2. Line } \\
\text { Balancing }\end{array}$} & $\begin{array}{l}\text { 1. Accept the LB } \\
\text { for the FSR Trial } \\
\text { stage }\end{array}$ & $\mathrm{H}-15$ & 28-Jan & 28-Jan & \\
\hline & & $\begin{array}{l}\text { 2. Line Balancing } \\
\text { Adjustments \& } \\
\text { Initial Production } \\
\text { Layout } \\
\text { Arrangements }\end{array}$ & $\mathrm{H}-11$ & 3-Feb & 3-Feb & \\
\hline
\end{tabular}




\begin{tabular}{|c|c|c|c|c|c|c|}
\hline Style & \multicolumn{6}{|l|}{ CK2946 } \\
\hline Area & \multicolumn{6}{|l|}{ SEWING } \\
\hline \multirow[t]{7}{*}{ Part } & \multicolumn{2}{|c|}{ Activity } & Deadline & Target & Status/Date & Note \\
\hline & \multirow{3}{*}{$\begin{array}{l}\text { 3. Transfer } \\
\text { The sewing } \\
\text { process on } \\
\text { TL \& GL } \\
\text { production }\end{array}$} & $\begin{array}{l}\text { 1. Supply of } \\
\text { sewing } \\
\text { components }\end{array}$ & H-15 & 28-Jan & 27-Jan & \\
\hline & & $\begin{array}{l}\text { 2. Making Job } \\
\text { break down sheets } \\
\text { for critical } \\
\text { processes }\end{array}$ & H-11 & $3-\mathrm{Feb}$ & 3-Feb & $\begin{array}{l}\text { Job break } \\
\text { down with TL } \\
\text { and GL }\end{array}$ \\
\hline & & $\begin{array}{l}\text { 3. Transfer } \\
\text { stitching process }\end{array}$ & $\mathrm{H}-12$ & 31-Jan & 31-Jan & \\
\hline & \multirow{3}{*}{$\begin{array}{l}\text { 4. Transfer of } \\
\text { stitching } \\
\text { process to } \\
\text { operators } \\
\text { process } \\
\text { critical }\end{array}$} & $\begin{array}{l}\text { 1. Allocation of } \\
\text { operators task }\end{array}$ & $\mathrm{H}-10$ & 4-Feb & 2-Feb & \\
\hline & & $\begin{array}{l}\text { 2. Material } \\
\text { preparation for } \\
\text { training of } \\
\text { operator }\end{array}$ & H-8 & 6-Feb & 3-Feb & $\begin{array}{l}\text { Using excess } \\
\text { material }\end{array}$ \\
\hline & & $\begin{array}{l}\text { 3. Teaching } \\
\text { operators critical } \\
\text { processes }\end{array}$ & $\mathrm{H}-7$ & 7-Feb & 4-Feb & $\begin{array}{l}\text { Stitch Backtab } \\
\text { Binding, Stitch } \\
\text { Foxing through } \\
\text { to Collar } \\
\text { Lining, Stitch } \\
\text { Eyestay to } \\
\text { Upper }\end{array}$ \\
\hline \multirow[t]{6}{*}{$\begin{array}{l}\text { Sewing } \\
\text { preparation }\end{array}$} & \multirow[t]{2}{*}{$\begin{array}{l}\text { 5. Quality } \\
\text { check point } \\
\text { training }\end{array}$} & $\begin{array}{l}\text { 1. Training quality } \\
\text { check point, key } \\
\text { manufacturing } \\
\text { process }\end{array}$ & H-6 & 10 -Feb & $5-\mathrm{Feb}$ & \\
\hline & & $\begin{array}{l}\text { 2. Understanding } \\
\text { PFC for TL and } \\
\text { operators }\end{array}$ & H-6 & $10-\mathrm{Feb}$ & $5-\mathrm{Feb}$ & \\
\hline & \multirow{4}{*}{$\begin{array}{l}\text { 6. Machine } \\
\text { preparation, } \\
\text { layout \& } \\
\text { sewing } \\
\text { process }\end{array}$} & $\begin{array}{l}\text { 1. Provide the } \\
\text { machines / tools } \\
\text { needed }\end{array}$ & $\mathrm{H}-10$ & 4-Feb & $1-\mathrm{Feb}$ & \\
\hline & & $\begin{array}{l}\text { 2. Provide serial } \\
\text { number stickers } \\
\text { for process } \\
\text { identification }\end{array}$ & $\mathrm{H}-10$ & 4-Feb & $1-\mathrm{Feb}$ & \\
\hline & & $\begin{array}{l}\text { 3. Provides } \\
\text { quality check } \\
\text { points and key } \\
\text { manufacturing } \\
\text { processes }\end{array}$ & & 4-Feb & $1-\mathrm{Feb}$ & \\
\hline & & $\begin{array}{l}\text { 4. Pasting the } \\
\text { serial number } \\
\text { according to the } \\
\text { sequence of } \\
\text { processes on the } \\
\text { table / machines. }\end{array}$ & $\mathrm{H}-10$ & 4-Feb & $2-\mathrm{Feb}$ & \\
\hline
\end{tabular}




\begin{tabular}{|c|c|c|c|c|c|}
\hline Style & \multicolumn{5}{|l|}{ CK2946 } \\
\hline Area & \multicolumn{5}{|l|}{ SEWING } \\
\hline \multirow[t]{8}{*}{ Part } & Activity & Deadline & Target & Status/Date & Note \\
\hline & $\begin{array}{l}\text { 5. Attachment of } \\
\text { quality check } \\
\text { points and key } \\
\text { manufacturing } \\
\text { processes to the } \\
\text { operator's desk }\end{array}$ & & 4-Feb & 2-Feb & \\
\hline & 6. Re layout & $\begin{array}{c}\text { H-6 } \\
(90 \mathrm{~min})\end{array}$ & $10-F e b$ & 7-Feb & $\begin{array}{l}\text { Re layout } 68 \\
\text { minute }\end{array}$ \\
\hline & $\begin{array}{l}\text { 7. machines and } \\
\text { tools setup }\end{array}$ & $\begin{array}{c}\mathrm{H}-6 \\
(60 \mathrm{~min})\end{array}$ & $10-\mathrm{Feb}$ & 7-Feb & $\begin{array}{l}\text { Machines } \\
\text { setup } 45 \\
\text { minute }\end{array}$ \\
\hline & $\begin{array}{l}\text { 8. First upper time } \\
\text { comes out }\end{array}$ & $\begin{array}{c}\mathrm{H}-6 \\
(30 \mathrm{~min})\end{array}$ & $10-\mathrm{Feb}$ & 7-Feb & $\begin{array}{l}\text { Total output } 84 \\
\text { pairs realized } \\
\text { on February } 7 \\
2020(D-3) \\
\end{array}$ \\
\hline & 7. Audit PFC & H-5 & $11-\mathrm{Feb}$ & 7-Feb & \\
\hline & 8. AQL Sewing & $\mathrm{H}-4$ & $12-\mathrm{Feb}$ & $12-\mathrm{Feb}$ & \\
\hline & $\begin{array}{l}\text { 9. Achievement of Sewing } \\
\text { Production Target (Ramp up } \\
\text { sewing target has been reached) }\end{array}$ & $\mathrm{H}-2$ & 14-Feb & 20-Feb & $\begin{array}{l}\text { The ramp up } \\
\text { was reached on } \\
\text { February } 20, \\
2020 \text {, there } \\
\text { was a problem } \\
\text { with adjusting } \\
\text { the ramp up } \\
\text { target, the } \\
\text { production } \\
\text { team followed } \\
\text { the old version } \\
\text { of the ramp up } \\
\text { target, which is } \\
702 \text { pairs for } \\
\text { today, while } \\
\text { the target for } \\
\text { the new } \\
\text { version is } 756 \\
\text { pairs for today. }\end{array}$ \\
\hline
\end{tabular}

Notes: From January 26 to February 12: Faster / On target; From February 20: Too late for target.

Table 6 was the follow-up product of the CK2946 sewing model framework, which entered the Sewing line on 18 February 2020, which achieved a 2-day ramp-up. Both activities were in line with the goal, but the achievement of this model's ramp-up goal was D+2 days. This situation was due to different interpretations of the output goals set by PPIC, as different goals influence the number of operator compositions and system requirements. The achievement of the ramp-up was better than the previous average, respectively $\mathrm{H}+13$ and 
$\mathrm{H}+20$ days. This improvement was helped by internal factors of production which were able to provide a better rapid change in time.

The dedication of all relevant departments (D7) to maintain the framework consistently is needed so that the same problem does not happen again. Management should be praised for the performance of the project team in achieving a better ramp-up for the new shoe model CK 2946. Rewards in the form of management rewards shall be issued at the end of the monthly meeting (D8).

\section{CONCLUSION}

The implementation of the SMED approach can have a substantial effect on the efficiency of the ramp-up process by changing the internal layout operations, the separation of the tasks of the operator, the attachment of quality control points, the training of critical processes, and the machine adjustment activities carried out by the mechanical team to external activities. The use of the Just In Time concept helps to ensure the consistency of the delivery of the necessary production items in preparation for ramp-ups between departments. The integration of SMED and JIT approaches into a new model system to provide shared visualization oversight that is easily understood by all departments in the implementation of ramp-up preparations. The 8-Dicipline method makes it simple to carry out any operation, from planning to tracking the results.

The implementation of the framework has increased the performance of the new shoe model type CK2946 to achieve the target $\mathrm{H}+2$ days. This can also be seen by the performance of the entire team in maintaining the punctuality of events within the framework that can be seen with the green colour code (visual management) accomplished in this model, even though certain events are still red. When compared to (Mulyana and Hasibuan, 2017), who improved system downtime by up to $75.59 \%$ by separating internal and external operations, splitting the workload of setup activities with two operators, and using geage software. This gauge tool speeds up the setup process by allowing you to connect the changing ring and stripper to the cartridge at the same time. However, the enhancements are limited to a narrower scope and only apply to a few machines. This study has a broad scope and includes a variety of methods (SMED, JIT, and others), making it slightly more complicated. Apart from having a large number of machines and processes, intense coordination between departments is required in order for the framework to running on time.

\section{ACKNOWLEDGEMENTS}

The authors would like to thank the Head of the Department of Lean at the shoe factory in Indonesia and Mercu Buana University for facilitating this study. 


\section{REFERENCES}

Agung, D. and Hasbullah, H., 2019. Reducing the Product Changeover Time Using Smed \& 5S Methods in the Injection Molding Industry. Sinergi, [e-jorunal] 23(3), p.199. DOI: 10.22441/sinergi.2019.3.004.

APICCAPS (the Portuguese Footwear, Components and Leather Goods Manufacturers' Association), 2020a. Footwear consumption to decline 22.5\%, world footwear yearbook. [online] Available at: <https://www.worldfootwear.com/news/footwear-consumption-to-decline-225in-2020/4746.html> [Accessed 20 August 2020].

APICCAPS (the Portuguese Footwear, Components and Leather Goods Manufacturers' Association), 2020b. Footwear production with new record of 24.3 billion pairs, world footwear yearbook. [online] Available at: <https://www.worldfootwear.com/news/footwear-production-with-new-recordof-243-billion-pairs/5356.html> [Accessed 20 August 2020].

APRISINDO (Indonesian Footwear Association), 2018. Indonesian Footwear Industry Country Report 2018. [pdf] Indonesian Footwear Association. Available at: <http://www.hkfootwear.org/content/upload/1539063579.pdf> [Accessed 14 May 2020].

Arief, F.N. and Ikatrinasari, Z.F., 2018. Perbaikan Waktu Setup Dengan Menggunakan Metode SMED Pada Mesin Filling Krim. Operational Excellence, 6(1), pp.1-8.

Black, C. and Létis, M.T., 2018. Sectoral Report Footwear Industry Brazil 2018. Novo Hamburgo: Brazilian Footwear Industries Association.

Briciu, S. and Ofileanu, D., 2015. Value Stream Mapping in the Romanian Footwear Industry. SEA - Practical Application of Science, III(07), pp.121-127.

Cotton, D., 2016. The Smart Solution Book: 68 Tools for Brainstorming, Problem Solving, and Decision Making. United Kingdom: Financial Times.

Dombrowski, U., Wullbrandt, J. and Krenkel, P., 2018. Industrie 4.0 in production ramp-up management. Procedia Manufacturing, 17, pp.1015-1022. DOI: $10.1016 /$ j.promfg.2018.10.085.

Esa, M.M., Rahman, N.A.A. and Jamaludin, M., 2015. Reducing High Setup Time in Assembly Line: A Case Study of Automotive Manufacturing Company in Malaysia. Procedia - Social and Behavioral Sciences, [e-journal] 211, pp.215-220. DOI: 10.1016/j.sbspro.2015.11.086.

Filla, J., 2016. The Single Minute Exchange of Die Methodology in a High-Mix Processing Line. Journal of Competitiveness, [e-journal] 8(2), pp.59-69. DOI: 10.7441/joc.2016.02.05. 
Gavali, R., Chavan, S. and Dongre, G.G., 2016. Set-up Time Reduction of a Manufacturing Line Using SMED Technique. International Research Journal of Engineering and Technologhy, 3(7), pp.1748-1750.

Gemba Academy, 1998. Preparing for the Kaizen Event. [online] Available Available at: <https://www.gembaacademy.com/school-of-lean/the-kaizen-waycourse/kaizen-overview> [Accessed 20 August 2020].

Huda, L., 2020. Kemenperin: Penjualan Alas Kaki Dalam Negeri Turun hingga 70 Persen. TEMPO.Co. Available at: $<$ https://bisnis.tempo.co/read/1374456/kemenperin-penjualan-alas-kaki-dalamnegeri-turun-hingga-70-persen/full\&view=ok> [Accessed 20 August 2020].

International Labour Organization, 2016. Wages and Productivity in The Garment Sector in Asia and the Pacific and The Arab States. International labor organization, 5(November), pp.1-8.

Jagtap, N.S., Ugale, V.D., Kadam, M.M., Kamble, S.S. and Salve, A.V., 2015. Setup Time Reduction of Machine Using SMED Technique and Lean Manufacturing. International Journal of Advances in Production and Mechanical Engineering, 1(2), pp.7-14.

Karam, A.A., Liviu, M., Veres, C. and Hore, R., 2018. The contribution of lean manufacturing tools to changeover time decrease in the pharmaceutical industry. A SMED project. Procedia Manufacturing, [e-journal] 22, pp.886-892. DOI: 10.1016/j.promfg.2018.03.125.

Kentli, A., Dal, V. and Alkaya, A.F., 2013. Minimizing machine changeover time in product line in an apparel industry. Tekstil ve Konfeksiyon, 23(2), pp.159-167.

Krishna, Y., 2020. Kemenperin Rancang Indonesia Footwear Network. Validnews.id, [online] 10 August. Available at: $<$ https://www.validnews.id/Kemenperin-Rancang-Indonesia-Footwear-NetworkBJV> [Accessed20 August 2020].

Maalouf, M.M. and Zaduminska, M., 2019. A Case Study of VSM and SMED in The Food Processing Industry. Management and Production Engineering Review, [e-journal] 10(2), pp.60-68. DOI: 10.24425/mper.2019.129569.

Mulyana, A. and Hasibuan, S., 2017. Implementasi Single Minute Exchange of Dies (SMED) Untuk Optimasi Waktu Changeover Model Pada Produksi Panel Telekomunikasi. Sinergi, [e-journal] 21(2), pp.107-114. DOI: 10.22441/sinergi.2017.2.005.

Pujiastuti, L., 2015. Pabrik Nike di Cianjur Mampu Produksi 1 Juta Pasang Sepatu/Bulan. detikFinance, [online] 27 October. Available at: $<$ https://finance.detik.com/industri/d-3054661/pabrik-nike-di-cianjur-mampuproduksi-1-juta-pasang-sepatubulan> [Accessed 6 May 2020]. 
Setyawan, L., 2019. Increasing the production capacity of copper drawing machine in the cable industry using SMED method: A case study in Indonesia. Operational Excellence, 11(1), pp.217-227.

Singla, M. and Pal, S., 2017. Reduction of Changeover Time During Style. National Institut of Fashion Technilogy.

Sunadi, S., Purba, H.H. and Hasibuan, S., 2020. Implementation of statistical process control through pdca cycle to improve potential capability index of drop impact resistance: A case study at aluminum beverage and beer cans manufacturing industry in indonesia. Quality Innovation Prosperity, [e-journal] 24(1), pp.104-127. DOI: 10.12776/QIP.V24I1.1401.

Syafei, M.Y. and Lokadipati, T., 2018. Improving Work System by Reducing Setup Time Activity in Drying Room in Pharmaceutical Industry with Single Minutes Exchange Die (SMED). JIE Scientific Journal on Research and Application of Industrial System, [e-journal] 3(1), pp.50-58. DOI: 10.33021/jie.v3i1.497.

Talekar, A. A., Patil, S.Y., Shinde, P.S. and Waghmare, G.S., 2019. Setup time Reduction Using Single Minute Exchange of Dies (SMED) at A Forging Line. B.S. Babu, K. Kumar, T.V. Vardhan and S. S. Kumar, eds. 1st International Conference On Manufacturing, Material Science and Engineering. Telangana, India, 16-17 August 2019. AIP Conference Proceedings. DOI: 10.1063/1.5141188.

Trimarjoko, A., Saroso, D.S., Purba, H.H., Hasibuan, S. Jaqin, CH. and Aisyah, S., 2019. Integration of nominal group technique, Shainin system and DMAIC methods to reduce defective products: A case study of tire manufacturing industry in Indonesia. Management Science Letters, [e-journal] 9(13), pp.2421-2432. DOI: 10.5267/j.ms1.2019.7.013.

Uzun Kocamiş, T., 2015. Lean Accounting Method for Reduction in Production Costs in Companies. International Journal of Business and Social Science, 6(91), pp.6-13.

Van Treeck, K., 2016. Wages and Productivity in The Garment Sector in Asia and the Pacific and The Arab States. International labor organization, 5(November), pp.1-8.

Zarghami, A. and Benbow, D., 2017. An Introduction to 8D Problem Solving. Milwaukee: ASQ Quality Press.

Zerin, N.H., Hossain, L. and Zannat, M., 2019. Manufacturing Lead Time Improvement by Reducing Changeover Time with The Application of SMED. International Journal of Scientific \& Engineering Research, 10(7), pp.2088-2092. 


\begin{abstract}
ABOUT AUTHORS
Lucky Setiawan ${ }^{0000-0003-0996-5688}$ (L.S.) - Universitas Mercu Buana, Jakarta, Indonesia, Industrial Engineering Master's Student, e-mail: lucky_setiawanita@yahoo.co.id.
\end{abstract}

Sawarni Hasibuan ${ }^{0000-0003-4477-4190}$ (S.H.) - Industrial Engineering Departement, Universitas Mercu Buana, Jakarta, Indonesia, Lecturer, e-mail: sawarni02@mercubuana.ac.id.

\title{
AUTHOR CONTRIBUTIONS
}

Conceptualization, L.S.; Methodology, L.S.; Validation, L.S.; Formal analysis, L.S.; Investigation, L.S.; Resources, L.S.; Data curation, L.S.; Original data preparation, L.S.; Writing, review and editing, S.H.; Supervision, S.H.; Advisor, S.H.

\section{CONFLICTS OF INTEREST}

The authors declare no conflict of interest. The funders had no role in the design of the study; in the collection, analyses, or interpretation of data; in the writing of the manuscript, or in the decision to publish the results.

(C) 2021 by the authors. Submitted for possible open access publication under the terms and conditions of the Creative Commons Attribution (CC-BY) license (http://creativecommons.org/licenses/by/4.0/). 